\title{
Boron and manganese fractions in dystrophic lake waters (Wigry National Park, NE Poland)
}

\author{
Adam Cudowski ${ }^{1}$, Andrzej Stefan Górniak ${ }^{1}$, Marta Hryniewicka ${ }^{2}$ \\ ${ }^{1}$ Department of Hydrobiology, Institute of Biology, University of Białystok, \\ Świerkowa 20B, 15-950 Białystok, Poland, e-mail: cudad@uwb.edu.pl (corresponding author), hydra@uwb.edu.pl \\ ${ }^{2}$ Department of General and Inorganic Chemistry, Institute of Chemistry, University of Białystok, \\ Hurtowa 1, 15-950 Białystok, Poland, e-mail: martah@uwb.edu.pl
}

\begin{abstract}
Physicochemical studies in four dystrophic lakes (Suchar Wielki, Suchar II, Suchar IV, and Wądołek) were carried out in

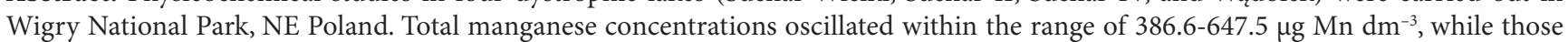
of soluble reactive manganese, 112.5-328.2 $\mu \mathrm{g} \mathrm{Mn} \mathrm{dm}{ }^{-3}$. Fairly high boron contents were recorded in the studied lakes, which amounted to $0.09-2.20 \mathrm{mg} \mathrm{B} \mathrm{dm}^{-3}$. The increase in dissolved reactive manganese (DRMn) and decrease in dissolved boron concentration with the lake depth were observed. Almost half (47\%) of the total manganese pool was composed of dissolved reactive soluble fraction (DRMn), then dissolved organic form (DOMn, 41\%), whereas the particulate fraction (PMn) made up the smallest share (12\%). Microbial decomposition of lake organic matter disappears and requirements of authotrophic plankton for $\mathrm{Mn}^{2+}$ decreases when the water temperature drops, thus the fraction prevails. The following regularity was recorded in all analysed dystrophic lakes: iron concentration decreases along with the depth, hence boron content can also be observed due to precipitated borates to bottom sediments, where they are accumulated.
\end{abstract}

Key words: manganese, boron, water, dystrophic lake, $\mathrm{pH}, \mathrm{DOC}$.

\section{Introduction}

Dystrophic lakes function due to a disharmonic system of environmental factors. Such lakes are distinguished by the small quantity of mineral substance dissolved in water (EC most often below $100 \mu \mathrm{S} \mathrm{cm}^{-1}$, waters are strongly acidic, and contain a remarkable content of dissolved organic matter (DOC 38.2-74.8

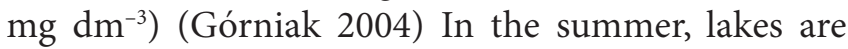
characterized by strong thermal-oxygen stratification and then there is a lack of oxygen at the depth of 2-3 metres at temperatures of about $7-9^{\circ} \mathrm{C}$ in the thermocline, that is within the photic zone range (Starmach et al. 1976; Wetzel 2001).

Dystrophic lakes provide excellent field conditions to study the types and forms (fractions) of specific metals in a huge range of oxygen concentrations in low $\mathrm{pH}$ values. Depending on environmental conditions, elements change their ionic forms through redox reactions that lead to a change in charge, thus they can be present at various oxidation numbers. Manganese and boron, counted among macronutrients of surface waters, are examples of such elements (Kabata-Pendias and Pendias 1999; Kabata-Pendias and Pendias 1979).

Boron plays a similar role in animals' and plants' organisms; however, knowledge on its presence in natural and surface waters is unusually poor. The element can produce 6 anionic forms and one nonionic form $\mathrm{H}_{3} \mathrm{BO}_{3}$. When an additional $\mathrm{OH}^{-}$group is attached to boric acid $\mathrm{B}(\mathrm{OH})_{3}, \mathrm{~B}(\mathrm{OH})_{4}$ is generated (Gonfiantini and Pennisi 2006). Acidity ( $\mathrm{pH}$ ) of surface waters determines the form of boron occurrence. Forms $\mathrm{B}(\mathrm{OH})_{4}^{-}$or $\mathrm{HBO}_{2}$ can be more often found in waters when total alkalinity increases. There are also known more complex ions such as $\left[\mathrm{B}_{5} \mathrm{O}_{6}(\mathrm{OH})_{4}\right]$, $\left[\mathrm{B}_{3} \mathrm{O}_{3}(\mathrm{OH})_{4}\right]^{-}$, and $\left[\mathrm{B}_{4} \mathrm{O}_{5}(\mathrm{OH})_{4}\right]^{2-}$, which are present mainly in waters with moderate $\mathrm{pH}$ values. Simple ions like $\mathrm{BO}_{3}{ }^{3-}$ or $\mathrm{BO}_{2}{ }^{-}$can be produced as a result of dissociation of borates (Gonfiantini and Pennisi 2006). 
Manganese can be present in fourteen different ionic forms at oxidation numbers from + II to + VII and depending on the form or ion charge, its availability for autotrophs varies (Wetzel 2001; Kabata-Pendias and Pendias 1999). Few hydro-chemical studies upon manganese refer mainly to sediments, soils or the water treatment process. Due to an important role of the element in algae and cyanobacteria development, its forms may determine the availability for autotrophs. In live organisms' cells, manganese takes part in photosynthesis, nitrogen conversions, and is considered as an "element for special tasks", because it is accumulated within enzymes (Miernik 1994). The manganese forms can be a key factor in algae growth too.

The present research aims at evaluating the manganese and boron concentrations in water of dystrophic lakes with low $\mathrm{pH}$ as well as manganese fraction structure under conditions of a strong summer thermal-oxygen stratification.

\section{Study area}

The summer study was carried out in four dystrophic lakes of Wigry National Park (WNP) located in north-eastern Poland. They are natural, mostly drainless lakes, situated in deep postglacial moraine depressions, surrounded by forests. They have a small area of a few hectares, usually without macrophytes and adjacent to a band of floating peat mosses Sphagnum, which are a significant source of humic substances in water (Górniak et al. 1999). This lake type contains a specific bottom sediment, called "dy" with high organic matter content above 90\% d.m. (Górniak 1996).

The water exchange rate in Suchar II Lake (S II) amounts to 0.31; in Suchar IV Lake (S IV) - 0.83; in Suchar Wielki Lake - 1.24; and in Wądołek - 0.95. This means that in Suchar II Lake water is exchanged once every three years. In Suchar Wielki Lake, water is exchanged once every 10 months; therefore the lake was classified (referring to the hydrological regime) as very active (Górniak ed. 2006).

All of the investigated dystrophic lakes are dimictic and are distinguished from other harmonic lakes of WNP by low water conductivity (below $150 \mu \mathrm{S} \mathrm{cm}^{-1}$ ) and high vertical thermal and oxygen gradients. A thin epilimnion layer (up to $2 \mathrm{~m}$ ) reaches high temperatures (about 23$25^{\circ} \mathrm{C}$ in summer), whereas bottom waters are only $4-6^{\circ} \mathrm{C}$ (Górniak 2004, 2006). Subsurface lake water layers are saturated with oxygen, while anaerobic conditions occur at 1-2 metres depth, thus large amounts of hydrogen sul- phide are produced. Waters of dystrophic lakes in WNP are of a particular yellow-brown colour and their colour intensifies with depth. The range of the photic zone in dystrophic lakes of WNP is small (only 1.5-3.0 m) and intensive development of photoautotrophic bacterioplankton (e.g. Chlorobium limicola Nads), having the ability to utilize the light as an energy source and carbon (IV) oxide, takes place at the anaerobic part of the metalimnion and the upper part of the hypolimnion (Czeczuga and Czerpak 1969; Górniak et al. 1999).

\section{Methods}

Temperature, electrolytic conductivity, water acidity $(\mathrm{pH})$, oxygen concentration, and oxygen saturation were measured at particular layers of the lakes (3-4 sampling depths in each lake in late summer) from a boat in the deepest lake point, using a multi-parameter probe Hydrolab Data Sonde 4. Water samples were collected applying a Limnos-type trap. Chemical analyses of water were performed at the laboratory directly after sampling by means of methods described by Hermanowicz et al. (1976). Dissolved organic carbon (DOC) content was determined with the organic carbon analyser TOC - 5050A (Shimadzu) according to the procedure recommended by Zieliński and Górniak (1999). Dissolved boron concentrations in water were analysed by means of the spectrophotometric method using 8-hydroxy-1-(salicylodenamino)-3,6-naphthalenodisulphonic acid $\left(\mathrm{C}_{17} \mathrm{H}_{12} \mathrm{NNaO}_{8} \mathrm{~S}_{2}\right)$. Measurements were made at $412 \mathrm{~nm}$ wavelength using acetate buffer at $\mathrm{pH}=4.75$, EDTA with NTA mixture, and azomethine$\mathrm{H}$ solution (Hermanowicz et al. 1997).

Concentrations of three manganese fractions were determined in the water of the studied lakes with the spectrophotometric method using formaldehyde with the authors' own modifications described earlier (Cudowski and Górniak 2008) and a phosphorus fraction using the molybdate spectrophotometric method. Concentrations of total phosphorus and manganese fractions (TP, TMn) (raw, non-filtered water), as well as dissolved fractions (DP, DMn) (water filtered through GF/C filter) were determined after UV digestion with concentrated sulphuric (VI) acid and 30\% hydrogen peroxide. Dissolved reactive phosphorus (DRP) and manganese fractions (DRMn) were analysed in samples filtered through GF/C filter with no digestion. Determinations of those three phosphorus and manganese fractions made it possible to calculate another two fractions in the following formulas: 
dissolved organic manganese fraction dissolved organic phosphorus fraction particular manganese fraction particular phosphorus fraction

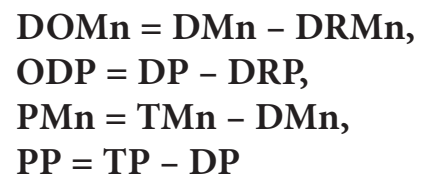

Additionally, using data of specific water conductivity, $\mathrm{pH}$, alkalinity and $\mathrm{DOC}$ from the epilimnion, the hydrochemical index of lake dystrophy (HDI) was calculated according to Górniak's formula (2004).

\section{Results and discussion}

Total manganese concentration (TMn) in water of the studied dystrophic lakes in Wigry National Park (WNP) oscillated within the range of 387-647 $\mu \mathrm{g} \mathrm{Mn}$ $\mathrm{dm}^{-3}$. The lowest concentration was recorded in subsurface Suchar Wielki Lake, while the highest in Suchar II Lake in the hypolimnion (Table 1). Dissolved reactive manganese (DRMn) in these waters were as follows: the minimum value $112.5 \mu \mathrm{g} \mathrm{Mn} \mathrm{dm}^{-3}$ was recorded in Suchar Wielki Lake in the littoral zone, while the maximum concentration of this fraction, as well as TMn, was found in the profundal zone of Suchar II Lake (Table 2). Dissolved organic fraction of Mn (DOMn) in Suchar II and Suchar IV Lakes reached peak concentrations within the littoral zone.

Boron concentrations in water of dystrophic lakes fell within a wide range from 0.09 to $2.2 \mu \mathrm{g} \mathrm{dm}^{-3}$; its maximum value was recorded in Suchar Wielki Lake, and the minimum in Suchar IV Lake (Fig. 1).

The investigated dystrophic lakes were dominated by dissolved reactive fraction (DRMn) making up to $60.5 \%$ of the TMn pool in Suchar IV Lake and only $46.1 \%$ in Suchar II Lake. In the remaining two lakes, Mn dissolved organic fraction (DOMn) prevailed. Aeration of surface water layers occurs during wind mixing; soluble manganese as $\mathrm{Mn}^{2+}$ is converted into $\mathrm{Mn}^{3+}$ or $\mathrm{Mn}^{4+}$, thus manganese is precipitated from a solution to sediments in the form of oxides and hydroxides.

Table 1. Morphometry of the investigated lakes and dystrophy level in lakes (Górniak 2006)

\begin{tabular}{lcccc}
\hline Parameters & Suchar II & Suchar IV & Suchar Wielki & Wądołek \\
\hline Surface [ha] & 2.5 & 1.0 & 8.4 & 1.1 \\
\hline Volume $\left[\mathrm{dam}^{3}\right]$ & 93.2 & 34.4 & 327.8 & 82.5 \\
\hline Max. Depth $[\mathrm{m}]$ & 10.0 & 8.0 & 9.6 & 15.0 \\
\hline Mean depth [m] & 3.6 & 3.2 & 3.6 & 8.6 \\
\hline Catchment area [ha] & 9.7 & 68.7 & 107.1 & 19.4 \\
\hline HDI - dystrophy index & 65.4 & 104.2 & 55.7 & 59.8 \\
\hline
\end{tabular}

Table 2. Concentrations of manganese fractions $\left[\mu \mathrm{g} \mathrm{dm}^{-3}\right]$ and boron $\left[\mathrm{mg} \mathrm{dm}^{-3}\right]$ in the investigated dystrophic lakes in NE Poland

\begin{tabular}{|c|c|c|c|c|c|}
\hline Lakes & Depth [m] & TMn & $\mathrm{DMn}$ & DRMn & B \\
\hline \multirow{4}{*}{ Suchar II } & 0.5 & 398.5 & 378.5 & 150.2 & 1.98 \\
\hline & 2.0 & 469.2 & 411.1 & 184.4 & 1.23 \\
\hline & 4.0 & 571.0 & 501.2 & 298.5 & 0.21 \\
\hline & 9.0 & 647.5 & 546.6 & 328.2 & 0.14 \\
\hline \multirow{4}{*}{ Suchar IV } & 0.5 & 404.8 & 364.8 & 179.8 & 1.76 \\
\hline & 1.5 & 438.2 & 418.9 & 286.2 & 0.27 \\
\hline & 4.0 & 479.5 & 465.2 & 313.7 & 0.13 \\
\hline & 6.0 & 489.1 & 481.4 & 321.6 & 0.09 \\
\hline Suchar Wielki & 0.5 & 386.6 & 327.8 & 112.5 & 2.20 \\
\hline Wądołek & 0.5 & 416.3 & 337.4 & 132.2 & 2.08 \\
\hline
\end{tabular}




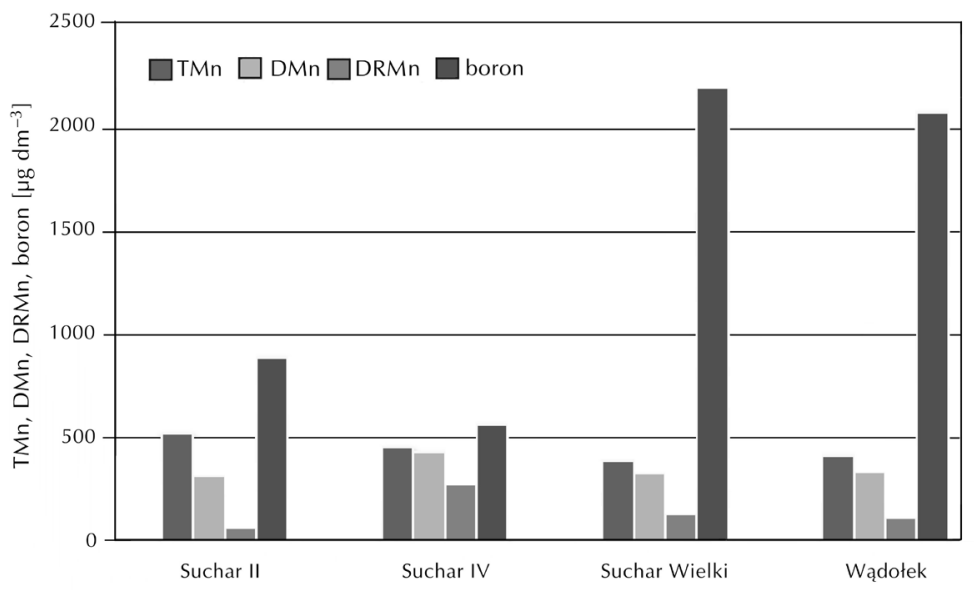

Fig. 1. Variability of manganese and boron concentrations in dystrophic lakes of WNP

An increase in the share of a particular fraction of phosphorus (PMn) in water of Suchar II and Wądołek Lakes (Fig. 2) was observed. Higher water alkalinity in surface layers affects the manganese complexation with organic matter, thus this fraction dominated in the water of both lakes (Table 2). An increase in DRMn fraction content with lake depth was observed: its percentage was 1.5-fold higher than in the benthic zone (Fig. 3). In the case of Suchar IV Lake, a remarkable decrease in the share of manganese seston fraction (PMn), and an over 6-fold decrease in value between surface and bottom layers, were observed (Fig. 3). Near surface lake water was dominated by soluble organic fraction (DOMn), while in other layers, soluble reactive fraction (DRMn) prevailed. Bacterioplankton within the metalimnion, which is aerated from time to time in summer, utilizes significant quantities of organic matter along with present DOMn fraction, which resulted in the increase in soluble reactive fraction (DRMn) in the near bottom layer in Suchar IV Lake (Fig. 3).

Boron concentration decreased, while soluble reactive manganese (DRMn) increased along with the increase oin water dystrophy presented as an HDI index (Fig. 4). It was probably the result of $\mathrm{Mn}^{2+}$ domination at strongly acidic water $\mathrm{pH}$ values and low concentrations of dissolved oxygen (Górniak 2006). The occurrence of DOC concentration did not significantly influence the fraction composition of manganese in dystrophic lakes as observed in eutrophic waters $(\mathrm{Cu}-$ dowski and Górniak 2008). Perhaps a strongly acidic environment caused the inhibition of the dissociation

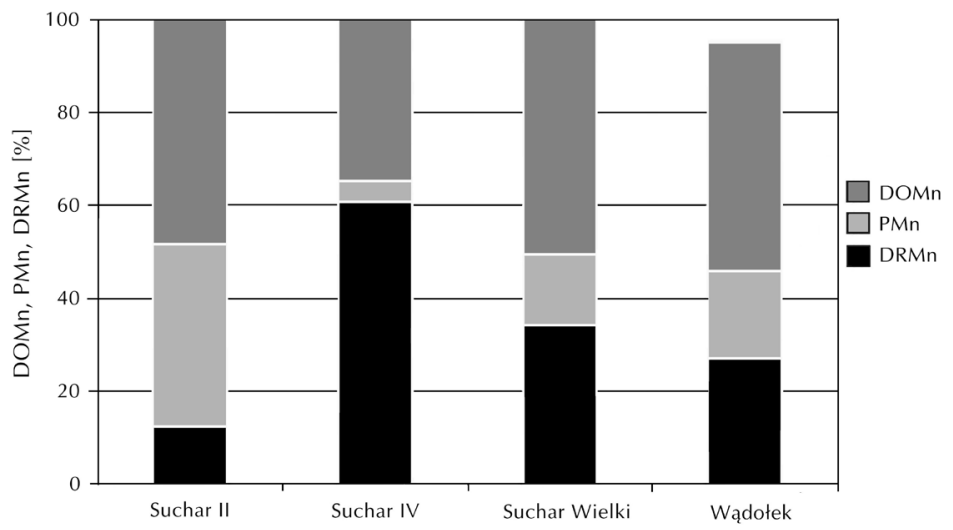

Fig. 2. Percentage of manganese fractions in dystrophic lakes of WNP 


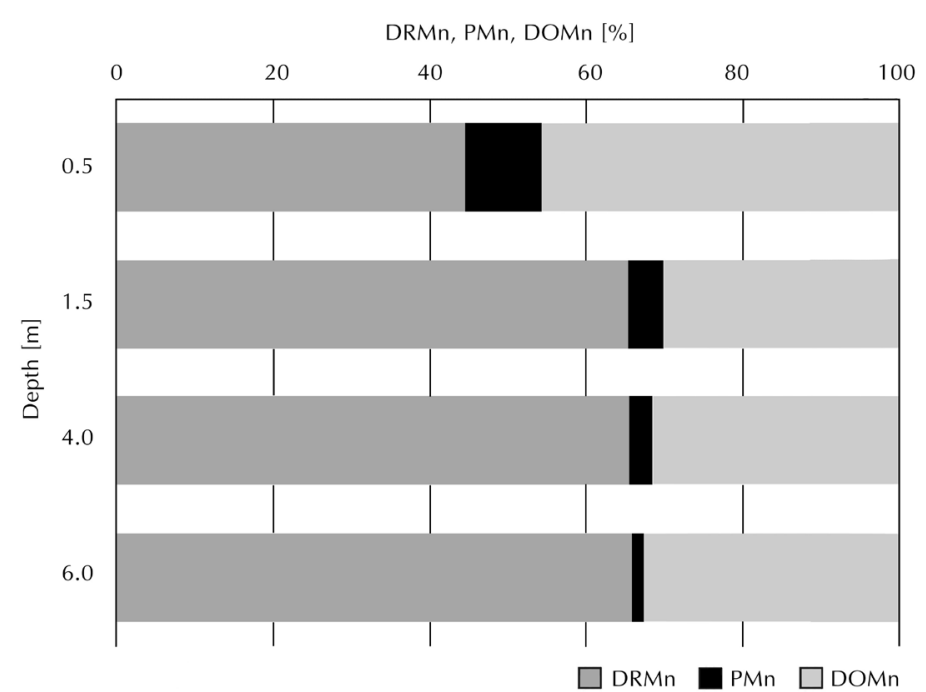

Fig. 3. Percentage of manganese fractions in water of dystrophic Suchar IV Lake

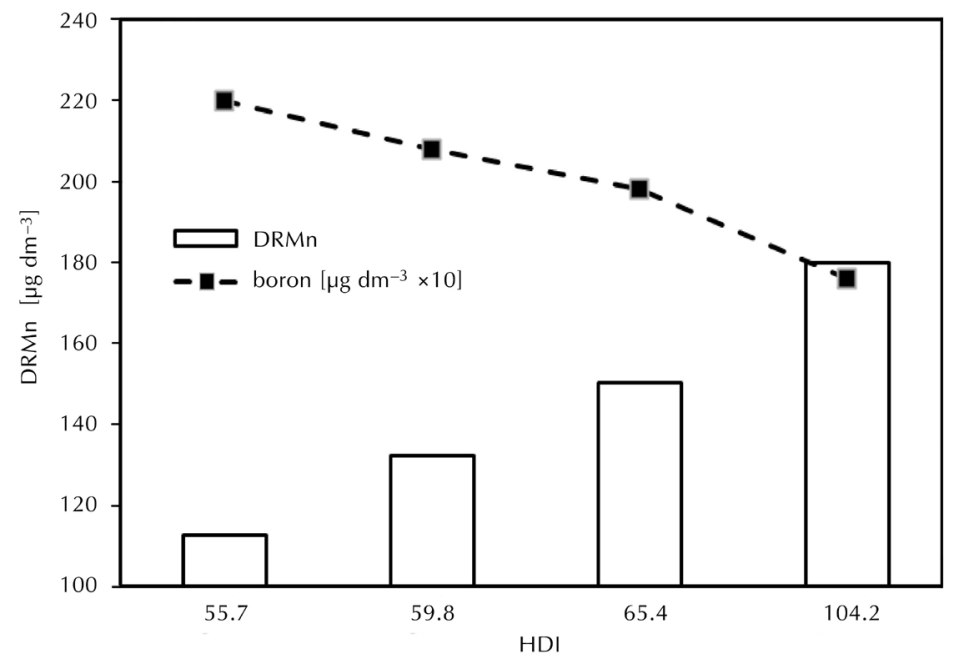

Fig. 4. Correlation between hydrochemical dystrophy index (HDI) and DRMn and boron concentrations in water of dystrophic lakes

of borates and simple boron ions like $\mathrm{BO}_{3}{ }^{3-}$ or $\mathrm{BO}_{2}^{-}$ were not decomposed, hence a decrease in boron concentration in waters was observed.

The specific functioning of dystrophic lakes allowed many surprising dependences referring to boron to be defined, which have not yet been found in harmonious lakes. A good example is the statistically significant correlation between dissolved boron and DOC concentrations. Up-to-date studies indicated a directly proportional correlation between the content of dissolved organic carbon in epilimnion vs. hypominion layers; however, such a dependence was not observed in the dystrophic lakes study by Chauveheid and Denis (2003). In acidic water the increase in the non-ionic form $\mathrm{H}_{3} \mathrm{BO}_{3}$ is noted, and dissociated and numerous anions of the type $\mathrm{BO}_{3}^{3-}, \mathrm{HBO}_{3}{ }^{2-}, \mathrm{H}_{2} \mathrm{BO}_{3}^{-}$, $\mathrm{BO}_{2}^{-}, \mathrm{B}_{4} \mathrm{O}_{7}^{2-}$, and $\mathrm{HB}_{4} \mathrm{O}_{7}^{-}$are formed. This appeared to be crucial, thus the increase in boron concentration was recorded (Fig. 5). In acidic conditions with higher Fe concentration in water, there may take place Fe hydroxide coprecipitation with boron (Gonfiantini and Pennisi 2006).

The small range of calcium concentration in waters of dystrophic lakes suggests that the element is not intensively utilized by hydrobionts or the lake is outside ground water movement. Due to the fact that decomposition of cell walls of living organisms (plant detritus) is the main source of boron in waters, 


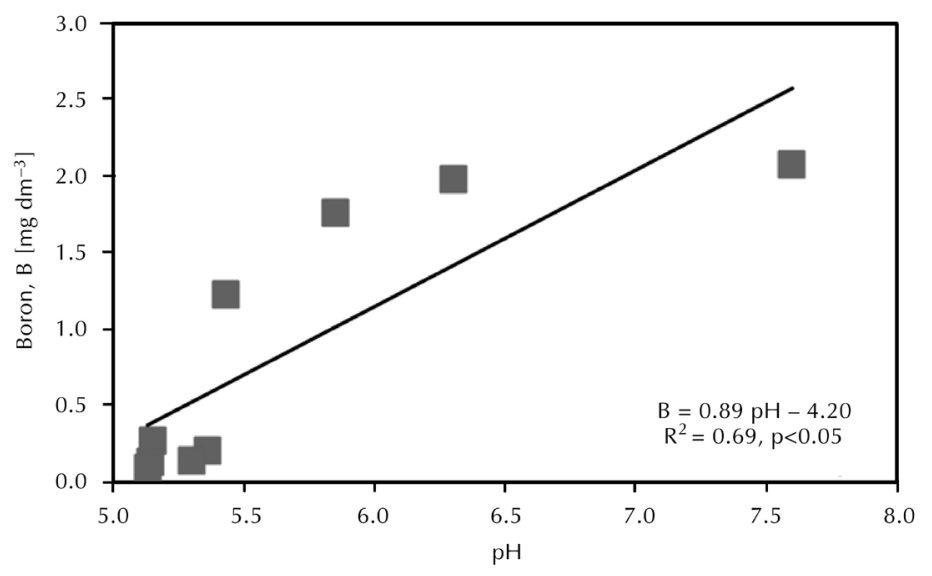

Fig. 5. Influence of water acidity $(\mathrm{pH})$ on boron concentrations in waters of dystrophic lakes

we can speculate that the number of organisms is low, thus an increase in calcium concentration (despite its low level) in water causes a decrease in boron content (Matoh 1998) (Fig. 6).
At the optimal oxygen saturation in surface layers, reactive manganese fraction (DRMn) makes up on average about $30 \%$ of the total manganese, while at low levels of dissolved oxygen below $50 \%$, the share of

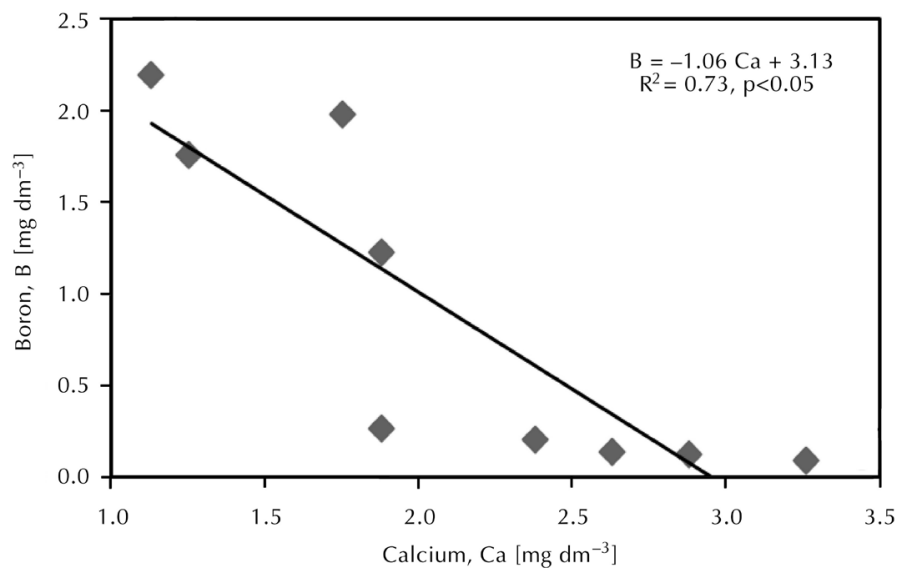

Fig. 6. Influence of calcium concentration in waters of dystrophic lakes of WNP

the fraction remarkably increases reaching even $65 \%$ at the hypolimnion. Because dystrophic lake epilimnion is very small (1-1.5m) and meta or hypolimnion layers are without dissolved oxygen, we assumed that DRMn fraction can dominate in the largest part of the volume of dystrophic lakes (Fig. 7).

Summing up all the above: low $\mathrm{pH}$ (acidity) and prolonged oxygen deficiencies during the whole year are crucial factors determining high manganese and boron concentrations in dystrophic lakes. High reactive manganese content in this type of water probably has a toxic influence on the development of living organisms, because the photosynthesis process is inhib- ited. Since the system performing the photosynthesis process absorbs radiation at two wavelengths, it was divided into two sub-systems. The water oxidation centre is the principal part of photosystem II, which is a manganese cluster (Miernik 1994). Despite the fact that the structure of the water oxidation centre has not been fully recognized, it is nevertheless known that manganese ions are coordinated with oxygen or nitrogen ligands that have the function of proton donor (Miernik 1994). Because of the high $\mathrm{Mn}^{2+}$ concentration in waters of dystrophic lakes, this causes saturation of the coordination cluster zone in algae cells, hence its conversion in such a way to be able 


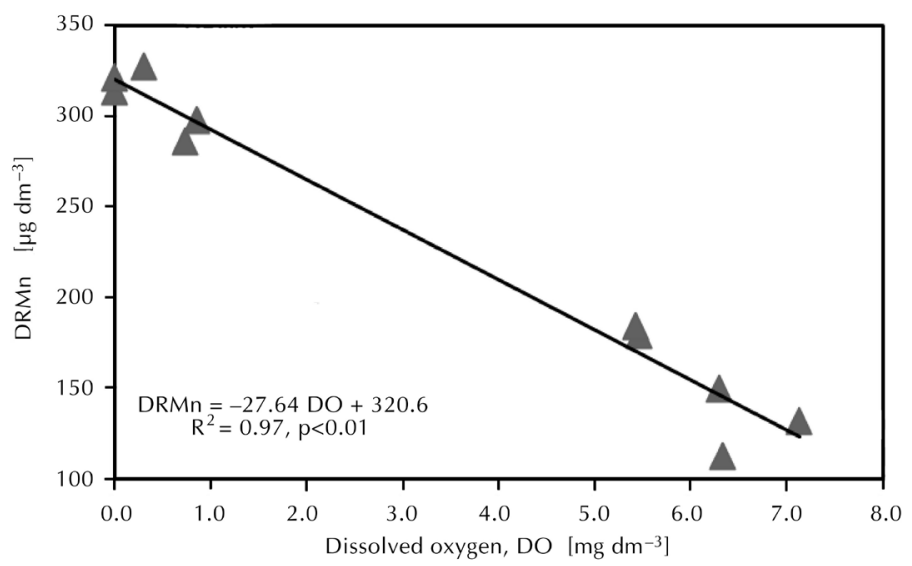

Fig. 7. Relationships between dissolved oxygen concentration vs. soluble reactive manganese concentration (DRMn) in waters of dystrophic lakes of WNP

to attach the water molecule and then liberate the proton to form an oxygen-oxygen bond. Phytoplankton photosynthesis is therefore inhibited, which has a destructive effect on the development of most autotrophic organisms, and many studies in dystrophic lakes confirm a very low level of plankton primary production (Wetzel 2001). Permanent lack of oxygen in the lower part of the photic zone and probably toxic DRMn concentrations in the hypolimnion and probably in sediment are limiting for macrophytes in the nearshore zone of dystrophic lakes. Higher water saturation by oxygen in dystrophic lakes of north eastern Poland occurs only in the situation of a decrease in water colour and/or increase in lake water $\mathrm{pH}$ and these facts are connected with the slow colonization of lakes by macrophytes and the evolution of the ecosystem to the next stage of lake development, called by Górniak (1996) humoeutrophic lakes.

\section{Conclusions}

1. Concentration of total manganese in water of dystrophic lakes oscillated from 386 to $647 \mu \mathrm{g} \mathrm{dm}^{-3}$, while that of boron concentration from 0.09 to $2.20 \mathrm{mg} \mathrm{dm}^{-3}$.

2. In the acidic and humic waters manganese is mainly composed of dissolved reactive and organic fractions and probably the DRMn form is toxic for water authotrophs. The lowest share in the manganese pool is of seston fraction.

3. Low water $\mathrm{pH}$ values in dystrophic lakes inhibit boron complexation reaction, which is not observed in harmonious lakes. Boron concentration decreased, while soluble organic manganese con- tent (DRMn) increased as did the level of lake dystrophy.

4. In dystrophic lakes, concentration of reactive dissolved manganese (DRMn) increased, whereas organic dissolved manganese (DOMn) decreased with lake depth.

5. Dissolved boron concentration decreased with depth in dystrophic lakes according to water $\mathrm{pH}$ changes, caused by boron coprecipitation with $\mathrm{Fe}^{3+}$ and sedimentation into the bottom as dy sediments.

\section{References}

Chauveheid E., Denis M., 2004, The boron - organic carbon correlation in water, Water Res. 38(7): 1663-1668.

Cudowski A., Górniak A., 2006, Effects of Narew river damming in the Siemianówka Reservoir on manganese forms in river water, Pol. J. Environ. Stud. 15(5D, Part II): 457-461.

Czeczuga B, Czerpak R., 1969, Studies on dynes found in Chlorobium limicola Nads (Chlorobacteriaceae) from the Wądołek Lake, Hydrobiologia 31: 561-571.

Gonfiantini R., Pennisi M., 2006, The behaviour of boron isotopes in natural waters and in water-rock interactions, J. Geochem. Explor. 88: 114-117.

Górniak A., 1996, Substancje humusowe i ich rola w ekosystemach słodkowodnych (Humus substances and their role in freshwater functioning), Diss Univ. Varsoviensis 448, Białystok, p. 151 (in Polish).

Górniak A. 2004, Zaawansowanie dystrofii sucharów Wigierskiego Parku Narodowego (Dystrophy advance in suchar type lakes of Wigry National Park), Rocz. Augustowsko-Suwalski 4: 45-52 (in Polish).

Górniak A. (ed.), 2006, Ekosystem zbiornika Siemianówka w latach 1990-2004 i jego rekultywacja (Ecosystem of the Siemianówka dam reservoir in the years 1990-2004 and its recultivation), Wyd. UwB, Białystok, p. 236 (in Polish). 
Górniak A., Grabowska M., Dobrzyń P., 1999, Fitoplankton trzech jezior dystroficznych Wigierskiego Parku Narodowego (Phytoplankton of three dystrophic lakes of Wigry National Park), [in:] Zdanowski B., Kamiński M., Martyniak A. (eds), Funkcjonowanie i ochrona ekosystemów wodnych na obszarach chronionych (Functioning and protection of aquatic ecosystems in protected areas), Wyd. IRŚ, Olsztyn: 361-370 (in Polish).

Górniak A., Jekatierynczuk-Rudczyk E., Dobrzyń P., 1999, Hydrochemistry of Three Dystrophic Lakes in Northeastern Poland, Acta Hydroch. Hydrob. 27(1): 12-18.

Górniak A., 2006, Jeziora Wigierskiego Parku Narodowego. Aktualna jakość i trofia wód (Lakes of the Wigry National Park. Current water quality and trophy), Wyd. UwB, Białystok, p. 176 (in Polish).

Hermanowicz W., Dożańska W., Dojlido J., Kosiorowski B., 1976, Fizyczno-chemiczne badanie wody i ścieków (Physico-chemical examination of water and wastewater), Arkady, Warszawa, p. 846 (in Polish).
Kabata-Pendias A., Pendias H., 1979, Pierwiastki śladowe w środowisku biologicznym (Trace elements in the biological environment), Wyd. Geol., Warszawa, p. 300 (in Polish).

Kabata-Pendias A., Pendias H., 1999, Biogeochemia pierwiastków śladowych (Biogeochemistry of trace elements), PWN, Warszawa, p. 397 (in Polish).

Matoh T., 1997, Boron in plant cell walls, Plant Soil 193: 5970.

Miernik D., 1994, Rola manganu w procesie fotosyntezy (The role of manganese in photosynthesis), Wiad. Chem. 48: 49-56 (in Polish).

Starmach K., Wróbel S., Pasternak K., 1976, Hydrobiologia. Limnologia (Hydrobiology. Limnology), PWN, Warszawa, p. 621 (in Polish).

Wetzel R.G., 2001, Limnology. Lake and river ecosystems, Academic Press, San Diego, p. 1066.

Zieliński P., Górniak A., 1999, Analizy rozpuszczonego węgla organicznego w wodach naturalnych, (Analyses of dissolved organic carbon in natural waters), Aparat. Bad. Dydakt. 3: 37-45 (in Polish, English summary). 